\title{
Increasing Intracellular Free Calcium Induces Circumferential Contractions in Isolated Cochlear Outer Hair Cells
}

\author{
Didier Dulon, ${ }^{a}$ Gary Zajic, and Jochen Schacht \\ Kresge Hearing Research Institute, The University of Michigan, Ann Arbor, Michigan 48109
}

The relationship between intracellular free calcium and the motile responses of outer hair cells isolated from the guinea pig cochlea was examined. Calcium levels were modulated by the addition of the calcium ionophores ionomycin or A23187 to the incubation medium and monitored with the fluorescent calcium indicator fluo-3. In the presence of 1.25 mM external calcium, the application of either ionophore (10 $\mu \mathrm{M})$ led to an increase of intracellular free calcium from 157 $\pm 76 \mathrm{~nm}$ to $1200 \pm 500 \mathrm{nM}$ within $30-60 \mathrm{sec}$. Concurrently, cells elongated by 1-2 $\mu \mathrm{m}$, cell diameter decreased, and cell volume shrank by $269 \pm 220 \mu \mathrm{m}^{3}(5.0 \pm 4.1 \%)$. The reduction in diameter was most pronounced in the middle portion of the cell $(4.4 \% \pm 4.2 \%)$, also evident in the apical region $(3.1 \% \pm 4.8 \%)$ but not significant in the basal region near the nucleus. This response was observed in outer hair cells from basal and apical turns of the cochlea and was reversed when the cells were rinsed with calcium-free medium supplemented with 2 mM EGTA. Optical imaging of the cell membrane with the potentiometric dye 1-(3-sulfonatopropyl)-4[ $\beta$ ] [2-(di-n-butylaminol)-6-naphthyl vinyl] pyridinium betaine during the elevation of intracellular calcium demonstrated features of contractility at the lateral cell membrane.

A rise in intracellular calcium as well as the motile response was still observed after a 5-min exposure of the cells to a calcium-free solution (supplemented with 2 mm EGTA), indicating that the ionophore was also able to liberate calcium from intracellular sites. However, depletion of calcium stores through prolonged incubation of the cells in calciumfree medium (30-60 min) suppressed both the calcium signal and the cell response. The calmodulin inhibitors trifluoperazine and pimozide $(30 \mu \mathrm{M})$ blocked the cell motility induced by ionomycin while they left the increase of intracellular calcium unaffected. These observations suggest that calciumdependent circumferential contractions in outer hair cells are mediated by calmodulin.

The application to the extracellular medium of putative neurotransmitters of the cochlear efferent system such as acetylcholine and GABA led to neither an increase in intracellular calcium nor a modification of cell shape. Therefore,

\footnotetext{
Received July 13, 1989; revised Oct. 30, 1989; accepted Nov. 6, 1989.

This study was supported by grants from the National Institutes of Health (NS05785) and from the Fondation Pour La Recherche Médicale (Paris, France).

Correspondence should be addressed to Dr. Jochen Schacht, Kresge Hearing Research Institute, The University of Michigan, 1301 E. Ann St., Ann Arbor, MI 48109-0506.

a Permanent address: Laboratoire d'Audiologie Expérimentale, INSERM 229, Université de Bordeaux II, Hôpital Pellegrin, 33076 Bordeaux, France.

Copyright (C) 1990 Society for Neuroscience $0270-6474 / 90 / 041388-10 \$ 02.00 / 0$
}

these neurotransmitters may not be directly involved in calcium-induced contractions in outer hair cells.

The circumferential contractions altered the stiffness of the plasma membrane and the turgor of the cell. Under normal conditions, changes in cell volume were inversely proportional to the osmotic pressure of the extracellular medium following van't Hoff's law. After the cells had been permeabilized for calcium by ionomycin, the relationship between cell volume and external osmotic pressure was still linear but the slope of the response curve was reduced by $50 \%$. This argues for calcium-dependent radial forces which increase the rigidity of the cell membrane and oppose eccentric forces due to water influx. Taken together with the morphological changes, these observations suggest the presence of a calcium-responsive, submembranous contractile cortex in outer hair cells which can develop tension and contractions.

The outer hair cells of the mammalian cochlea are thought to be involved in an active process during auditory transduction. By regulating and amplifying the micromechanics of the basilar membrane, these cells may be responsible for the fine-tuning characteristics of the eighth nerve fibers innervating the inner hair cells which are considered the primary auditory transducers (Dallos, 1985; Neely and Kim, 1986). The hypothesis of an active mechanical component generated by the outer hair cells has recently been reinforced by the observation that these cells are able to elicit axial forces at acoustic frequencies (above 1 $\mathrm{kH}$ ) when electrically stimulated in vitro (Brownell et al., 1985; Ashmore, 1987; Zenner et al., 1987). These "fast" electrically induced shape changes do not directly require energy substrates in vitro, e.g., ATP (Kachar et al., 1986), and appear to be unrelated to muscle-like actomyosin-dependent contractions (Ashmore, 1987; Zenner et al., 1987). Although the site of the electromechanical event is presumed to be closely associated with the plasma membrane (Holley and Ashmore, 1988), the molecular mechanism underlying these electromechanical properties remains unknown. Moreover, the physiological signal triggering such cellular response also remains to be demonstrated. So far, no direct evidence has been presented that the deflection of the hair bundles of the outer hair cells can lead to cell depolarization and mechanical motion of the cell body.

Another type of motility, characterized as a "slow" contraction, has also been demonstrated in isolated outer hair cells and is thought to involve contractile proteins. The cells shorten in response to the application of calcium/ATP after detergent permeabilization of the plasma membrane (Flock et al., 1986; Zenner, 1986) or by passive intracellular injection (Dulon et al., 
1988). However, these calcium-induced contractile responses and their role in cochlear physiology remain to be clarified, in part because they appear to be irreversible and because direct measurements of intracellular calcium concentrations in relation to the observed motility have not been conducted. Moreover, the physiological stimuli triggering such "slow" contractions are still unknown. They could originate from the action of the medial efferent system, which preferentially innervates outer hair cells with greatest innervation in basal turns and in the first rows (for review, see Warr et al., 1986). The neurotransmitter most likely involved in these efferent synapses is acetylcholine (Eybalin and Pujol, 1987), although its role in cochlear physiology remains to be defined. Furthermore, GABA is also found associated with efferent synapses in the apex of the cochlca (Eybalin ct al., 1988).

In this study we investigated the role of intracellular calcium in the contractile responses of outer hair cells. Intracellular calcium levels were modulated by the ionophoric antibiotics ionomycin and A23187 (Reed and Lardy, 1972; Liu and Hermann, 1978) and monitored by the fluorescent calcium indicator fluo-3 (Minta et al., 1989). Fluorescent molecular probes are wellestablished, powerful tools for studying changes in intracellular calcium in living isolated cells (Fay et al., 1979; Tsien et al., 1982; Williams et al., 1985).

In order to test if the putative neurotransmitters of the cochlear efferent system can trigger an increase in intracellular calcium and cell contraction, we investigated the effect of acetylcholine and GABA on intracellular calcium levels and cell shape. Furthermore, we tested the possible involvement of calmodulin and protein kinase $\mathrm{C}$ in outer hair cell contractions by examining the effects of 2 calmodulin antagonists, trifluoperazine and pimozide, and the effect of a protein kinase $\mathrm{C}$ activator, phorbol ester.

We also determined whether calcium-induced contractions in hair cells were accompanied by changes in intracellular pressure. Outer hair cells are sensitive to the osmolality of their incubation medium and react to hypotonicity by swelling and shortening and to hypertonicity by shrinking in diameter and elongating (Dulon et al., 1987). These osmotic shape changes are neither calcium- nor contractile protein-dependent. We studied the influence of intracellular calcium levels on cell volume changes in response to hypotonic challenge.

\section{Materials and Methods}

Cell preparation. Pigmented guinea pigs (280-340 gm) were decapitated and the temporal bones quickly removed. The bulla and the bony walls of the cochlea were immediately opened and the organ of Corti dissected. In order to differentiate basal and apical outer hair cells, the 2 first turns (from the base of the cochlea) and the 2 apical turns of the organ of Corti were collected and sampled separately. These were kept at room temperature $\left(20-22^{\circ} \mathrm{C}\right)$ in Hank's Balanced Salt Solution (HBSS: 137 $\mathrm{mm} \mathrm{NaCl}, 5.4 \mathrm{mM} \mathrm{KCl}, 1.25 \mathrm{~mm} \mathrm{CaCl}_{2}, 0.5 \mathrm{mM} \mathrm{MgCl}_{2}, 0.4 \mathrm{mM} \mathrm{MgSO}_{4}$, $0.33 \mathrm{mM} \mathrm{Na}_{2} \mathrm{HPO}_{4}, 0.44 \mathrm{~mm} \mathrm{KH} \mathrm{KO}_{4}, 5.5 \mathrm{~mm}$ D-glucose; Gibco Laboratories, Grand Island, NY) buffered to $\mathrm{pH} 7.4$ with $5 \mathrm{~mm}$ sodium HEPES (Dulon et al., 1987; Zajic and Schacht, 1987). After a 10-min incubation with $0.5 \mathrm{mg}$ collagenase (type IV; Sigma, St. Louis, MO) per $\mathrm{ml}$ HBSS, the cells were mechanically dispersed by gentle flux through a micropipette. Before adopting the isolation procedure described above, we had compared enzymatically isolated hair cells to those simply isolated by mechanical treatment. Similar cell responses to ionophores were observed for both procedures. Treatment with collagenase was the technique adopted because a higher yield of isolated cells could be obtained.

The length of isolated cells ranged from 30 to $50 \mu \mathrm{m}$ for basal and 65 to $80 \mu \mathrm{m}$ for apical cells.
F-actin labeling with TRITC-phalloidin. In order to visualize the intracellular organization of F-actin, a modification of the procedure described by Thorne et al. (1987) was used. The cells first were rapidly permeabilized by a short exposure ( $30-60 \mathrm{sec}$ ) to HBSS containing $25 \%$ dimethyl sulfoxide (DMSO; Sigma, St. Louis, MO) or $0.1 \%$ triton X-100 followed by a 1 - to 2 -min exposure to $10 \mu \mathrm{M}$ tetramethylrhodamineisothiocyanate-phalloidin (TRITC-phalloidin; Sigma, St. Louis, MO). The cells were then rinsed with HBSS and observed under fluorescence microscopy. This technique provided a more distinct staining of $F$-actin in the lateral cell wall.

Cell loading with fluo-3 and calcium imaging. One-millimolar stock solutions of the permeant acetoxy methyl ester derivative of fluo-3, fluo3/AM (Molecular Probes Inc., Eugene, OR) were prepared in dry DMSO and stored below $0^{\circ} \mathrm{C}$. For dye loading, hair cells were incubated for 30 $\mathrm{min}$ at room temperature $\left(22-25^{\circ} \mathrm{C}\right)$ with fluo-3/AM diluted in HBSS to a final concentration of $2 \mu \mathrm{M}$. The cells were maintained in a $50-\mu \mathrm{l}$ droplet of HBSS on glass cover slips (thickness, $0.13 \mathrm{~mm}$ ) in a saturated humid chamber (to prevent evaporation and changes in osmolality of the medium) and subsequently carefully rinsed with HBSS.

Cells loaded with fluo- 3 were observed with an inverted microscope (Leitz Fluovert) fitted with an epifluorescence system (ArcLamp HBO 100W; a $450-490 \mathrm{~nm}$ band pass exciter filter, $510 \mathrm{~nm}$ dichroic mirror and a $520 \mathrm{~nm}$ barrier filter for excitation and emission, respectively) and a Leitz 160/- NPL FLUOTAR 50/1.00 oil immersion objective. In order to prevent photobleaching, the excitation irradiance was reduced by a $97.5 \%$ neutral density filter to $0.14 \times 10^{5}$ watt $/ \mathrm{m}^{2}$. Under these conditions, no significant photobleaching was noted with continuous illumination of 2 min (maximal exposure time in this study).

Cell fluorescence was monitored via a Silicon Intensified Target video camera (SIT 66, Dage-MTI Inc., Michigan City, IN) and recorded for analysis on a videocassette recorder (Mitsubishi SuperVHS model HS423UR). The recorded images were analyzed with a Quantex QX-7210 image processing system (Quantex Corp., Sunnyvale, CA). Sixteen to thirty-two sequential frames from the videocassette recorder or the camera were averaged and the fluorescence intensity of the ccll images was measured by averaging the pixel radiance value of the entire cell.

The relation between $\left[\mathrm{Ca}^{2+}\right]$ and fluorescence intensities of fluo- 3 was determined under our experimental conditions by illuminating through the microscope, at $450-490 \mathrm{~nm}$, small volumes of calibrating solutions containing $25 \mu \mathrm{M}$ fluo-3 pentapotassium salt and calcium-buffered calibrating solutions at various concentrations (World Precision Instruments, New Haven, CT). The fluorescence intensities of fluo-3 obtained as a function of $\left[\mathrm{Ca}^{2+}\right]$ are plotted in Figure 1. Scatchard analysis indicated a dissociation constant of the $\mathrm{Ca}^{2+}$ complex of fluo-3 of approximately $420 \mathrm{~nm}$ in agreement with the original reports of Minta et al. (1989) and Kao et al. (1989).

Fluo-3 signals from the isolated hair cells were calibrated by using a heavy metal as described by Kao et al. (1989). The concentrations of intracellular calcium were estimated according to the cquation:

$$
[\mathrm{Ca} 2+]_{\mathrm{i}}=K_{\mathrm{d}}\left(F-F_{\text {rin }}\right) /\left(F_{\max }-F\right)
$$

$K_{\mathrm{d}}$ is the dissociation constant for the fluo-3/calcium complex; $F$ is the observed fluorescence in arbitrary units of intact fluo-3 loaded cells; $F_{\max }$ (fluorescence maximum) was calculated from the cquation $F_{\max }=$ $\left(F_{\mathrm{Mn}}-F_{\mathrm{bkg}}\right) / 0.2+F_{\mathrm{bkg}} . F_{\mathrm{Mn}}$ is the fluorescent signal obtained after treatment of the cells with ionomycin $(10 \mu \mathrm{M} ; 60 \mathrm{sec})$ and $\mathrm{MnCl}_{2}(2$ $\mathrm{mM} ; 3-5 \mathrm{~min}) ; F_{\mathrm{bkg}}$ is the fluorescent signal obtained after lysis of the cells with $100 \mu \mathrm{g}$ saponin $/ \mathrm{ml} ; 0.2$ is the ratio of the signal of the $\mathrm{Mn}^{2+}$. saturated fluo-3 to that of the $\mathrm{Ca}^{2+}$-saturated dye. $F_{\min }$ (fluorescence minimum) was calculated from the equation $F_{\min }=\left(F_{\max }-F_{\mathrm{bkg}}\right) / 40+$ $F_{\text {bkg }}$, where 1/40 is the ratio of the fluorescent signal of metal-free fluo-3 to the $\mathrm{Ca}^{2+}$ complex.

The calculations of calcium concentrations in our study assume that the dye inside cells behaves similarly to dye in vitro, with regard to the $K_{\mathrm{d}}$ value for $\mathrm{Ca}^{2+}$. This assumption is supported for fluo- 3 by Kao et al. (1989), who estimated that $98 \%$ of intracellular fluo-3 resides in the cytosol and showed that the $K_{\mathrm{d}}$ for calcium was similar in salt solutions and in the presence of a cell lysate. It should be notcd that this is in contrast to the calcium-indicator fura-2, which binds to intracellular protein and undergoes a significant shift in its $K_{\mathrm{d}}$ (Konishi et al., 1988).

Optical imaging of the cell membrane with the potentiometric dye di4-ANEPPS. Hair cells were incubated for $5 \mathrm{~min}$ in HBSS with $0.5 \mu \mathrm{M}$ of 1-(3-sulfonatopropyl)-4-[ $\beta$ ] [2-(di- $n$-butylamino)-6-naphthyl vinyl] pyridinium betaine (di-4-ANEPPS, Molecular Probes Inc., Eugene, OR; Gross et al., 1986). The cells were rinsed with HBSS and observed under 


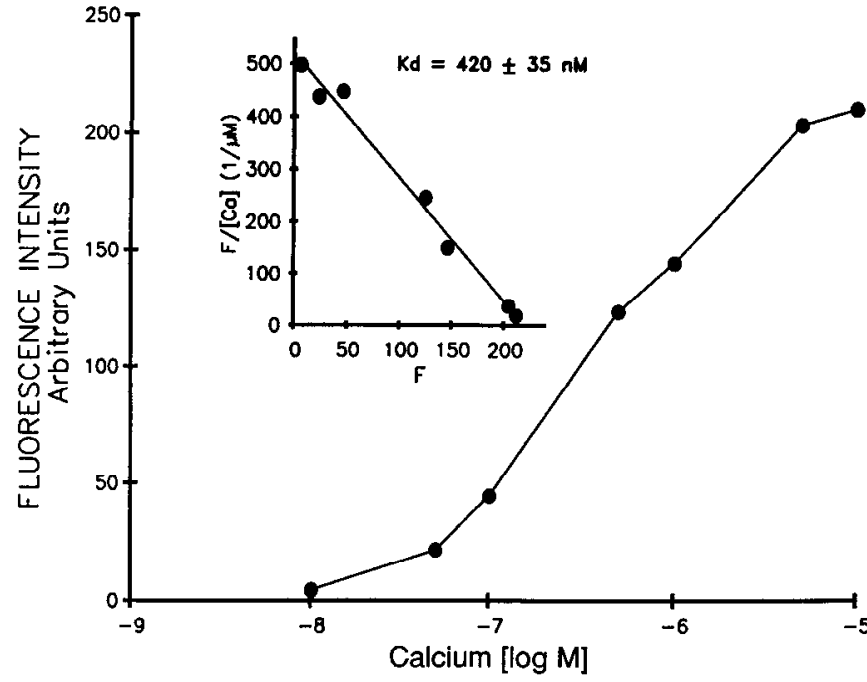

Figure 1. Calibration curve of fluo-3. The intensities of fluorescence measured with the SII camera are plotted as a function of $\left[\mathrm{Ca}^{2+}\right]$. Inset, The corresponding Scatchard plot $(F=$ fluorescence intensity in arbitrary units).

fluorescence microscopy (band-pass filter excitation was 530-560 nm, reflection short-pass filter $580 \mathrm{~nm}$, and long-pass filter $580 \mathrm{~nm}$ ).

Application of calcium ionophores, tetraethylammonium chloride (TEA), calmodulin inhibitors, phorbol ester, acetylcholine, carbachol, and $G A B A$. Ten-millimolar stock solutions of ionomycin and A23187 (from Calbiochem, La Jolla, CA) were prepared in DMSO and ethanol, respectively. The ionophores were added to the cells to yield a final concentration of $10 \mu \mathrm{M}$ (final concentration of DMSO or ethanol, $0.1 \%$ ).

TEA was applied to the cells at a final concentration of $25 \mathrm{~mm}$ in HBSS.

The calmodulin inhibitors trifluoperazine hydrochloride and pimozide (Sigma, St. Louis, MO) were applied to the cells at a final concentration of $30 \mu \mathrm{M}$ in HBSS $30 \mathrm{~min}$ before the calcium ionophore.

Phorbol 12-myristate 13-acetate (TPA; Sigma, St. Louis, MO) was applied to the cells at final concentrations ranging from 50 to $200 \mu \mathrm{M}$ in HBSS. Acetylcholine chloride, carbachol, and GABA (Sigma, St. Louis, MO) were applied at final concentrations ranging from 20 to $1000 \mu \mathrm{M}$.

In order to obtain the final concentrations, $5 \mu \mathrm{l}$ of the respective chemical were added with a micropipette to the 50- $\mu$ ldroplet containing the cells. Considering the small amount of medium, it can be assumed that diffusion of the chemical toward the cells was immediate. This is supported by the fact that cellular reactions were observed within seconds after addition of the calcium-ionophore. In order to keep the osmolality of the extracellular medium constant, medium containing the chemicals was iso-osmolar. The osmolality of all solutions was adjusted to $300 \pm 2 \mathrm{mOsm}$.

Application of hypotonic media. Hypo-osmotic media of osmolalities of 268 and 244 mOsm were obtained by lowering the glucose concentration of the HBSS. The medium of 217 mOsm was prepared from HBSS without glucose by further diluting with water. Before exposure to the media of different osmolalities, the cells were pretreated with ionomycin $(10 \mu \mathrm{M})$ for $60 \mathrm{sec}$ in regular HBSS $\left(1.25 \mathrm{mM} \mathrm{CaCl}_{2}\right)$ or in calcium-free HBSS (supplemented with 2 mM EGTA). The length and diameter of the cells were measured before and $30 \mathrm{sec}$ after the addition of ionomycin and $120 \mathrm{sec}$ after the application of iso- $(300 \mathrm{mOsm})$ or hypo-osmotic solutions (268, 244, or 217 mOsm).

Cell length and volume measurements. Cell length was simultaneously monitored with the fluorescence or separately on bright-field images and analyzed with the Quantex-QX-7-210. The system provided measurements with a resolution of $\pm 0.2 \mu \mathrm{m}$ as tested with fluorescent microspheres of known diameter (Polysciences, Warmington, PA). The cell lengths reported are the distance between the cuticular plate and the synaptic ending of the cell. The cells considered in this study retained their straight shape with few exceptions. For a light curvature of the cell body, the length was measured in segments following the curve. When a dramatic curving of the cell body occurred during treatment, the cell was rejected.

The cell volume was estimated from the 2-dimensional video images of the cells observed in bright-field microscopy assuming that the outer hair cells were cylindrical. Since the diameter varied along the length of the cell, each hair cell was divided for measurements into segments of 10-15 $\mu \mathrm{m}$ length. Such segments were sufficiently small so that the cell diameter was approximately constant.

\section{Results}

Effects of the ionophores A23187 and ionomycin on intracellular calcium levels

The concentration of cytosolic free calcium in outer hair cells kept in vitro for $1-2 \mathrm{hr}$ after dissociation averaged $157 \mathrm{nM} \pm$ $76(n=10)$. The addition of the calcium ionophores ionomycin or A23187 $(10 \mu \mathrm{M})$ in the presence of $1.25 \mathrm{~mm}$ extracellular calcium led to a large, rapid increase of the cytosolic fluorescent signal of fluo-3, indicating calcium entry along its concentration gradient (Fig. 2). The 2 ionophores induced a similar response, with fluorescence increasing by $100-200 \%$ within $30-60 \mathrm{sec}$ (Table 1), corresponding to an increase of the calcium concentration to $1200 \pm 500 \mathrm{~nm}(n=8)$.

The increase of calcium through the ionophores occurred in the entire cell and appeared to be uniform along the cell body. The level of fluorescence in the area under the cuticular plate, the nucleus area, and the cytoplasm all increased to a similar extent (Fig. 2). The higher level of fluorescence observed in the

Table 1. Effects of the calcium ionophores ionomycin and $\mathbf{A 2 3 1 8 7}$ on the cell length and intracellular calcium levels of basal and apical outer hair cells

\begin{tabular}{llr} 
Medium of stimulation & $\begin{array}{l}\text { Changes in } \\
\text { length (\%) }\end{array}$ & $\begin{array}{l}\text { Increase of fluo-3 } \\
\text { fluorescence (\%) }\end{array}$ \\
\hline Apical outer hair cells & & \\
A23187 $(10 \mu \mathrm{M})$ in HBSS with $1.25 \mathrm{mM} \mathrm{Ca}^{2+}$ & $+1.7^{a} \pm 2.0$ & $147^{a} \pm 87(n=15)$ \\
Ionomycin $(10 \mu \mathrm{M})$ in HBSS with $1.25 \mathrm{mM} \mathrm{Ca}^{2+}$ & $+1.6^{a} \pm 1.3$ & $95^{a} \pm 33(n=22)$ \\
Ionomycin $(10 \mu \mathrm{M})$ in HBSS without $\mathrm{Ca}^{2+}\left(\mathrm{EGTA}^{2} \mathrm{mM}\right)$ & $+0.1 \pm 0.5$ & $3 \pm 7(n=8)$ \\
DMSO $(0.1 \%)$ in HBSS with $1.25 \mathrm{mM} \mathrm{Ca}{ }^{2+}$ & $-0.1 \pm 0.6$ & $2 \pm 5(n=5)$ \\
Basal outer hair cells & & \\
Ionomycin $(10 \mu \mathrm{M})$ in HBSS with $1.25 \mathrm{mM} \mathrm{Ca}^{2+}$ & $+4.0^{a} \pm 1.9$ & $40^{a} \pm 19(n=8)$
\end{tabular}

Intracellular calcium was monitored as described in Methods with the fluorescent dye fluo-3. The cell length and intracellular fluorescence of fluo-3 were measured before and after the application of the ionophores. Apical cells were $60-80 \mu \mathrm{m}$, basal cells were $30-50 \mu \mathrm{m}$ long.

${ }^{a}$ Different from controls, $p<0.01$. All other differences are not significant. 


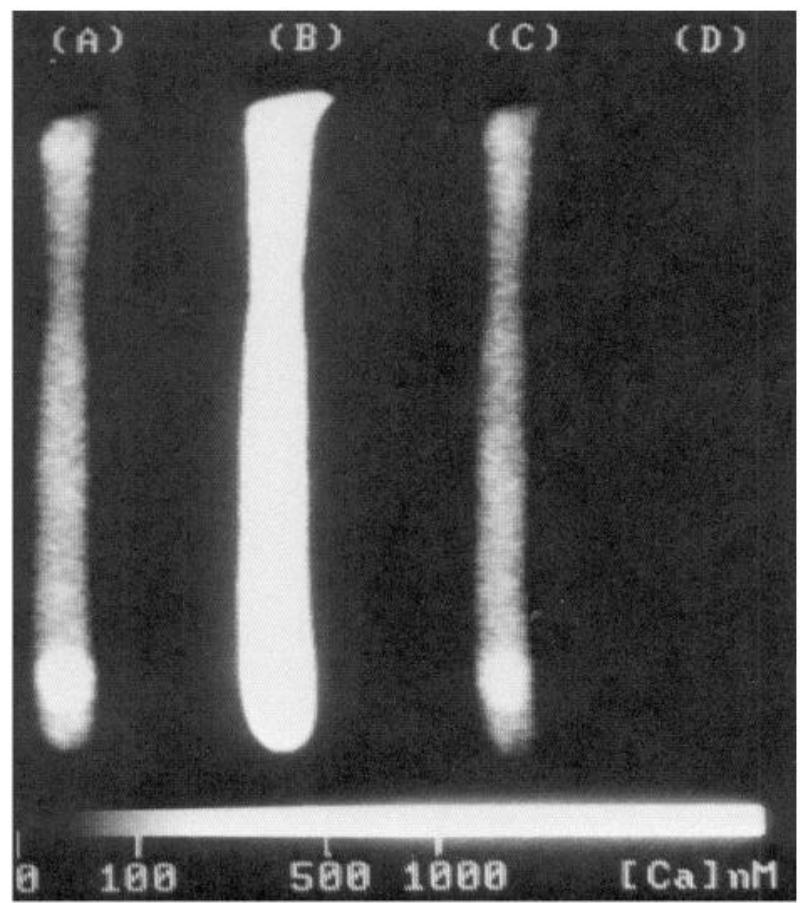

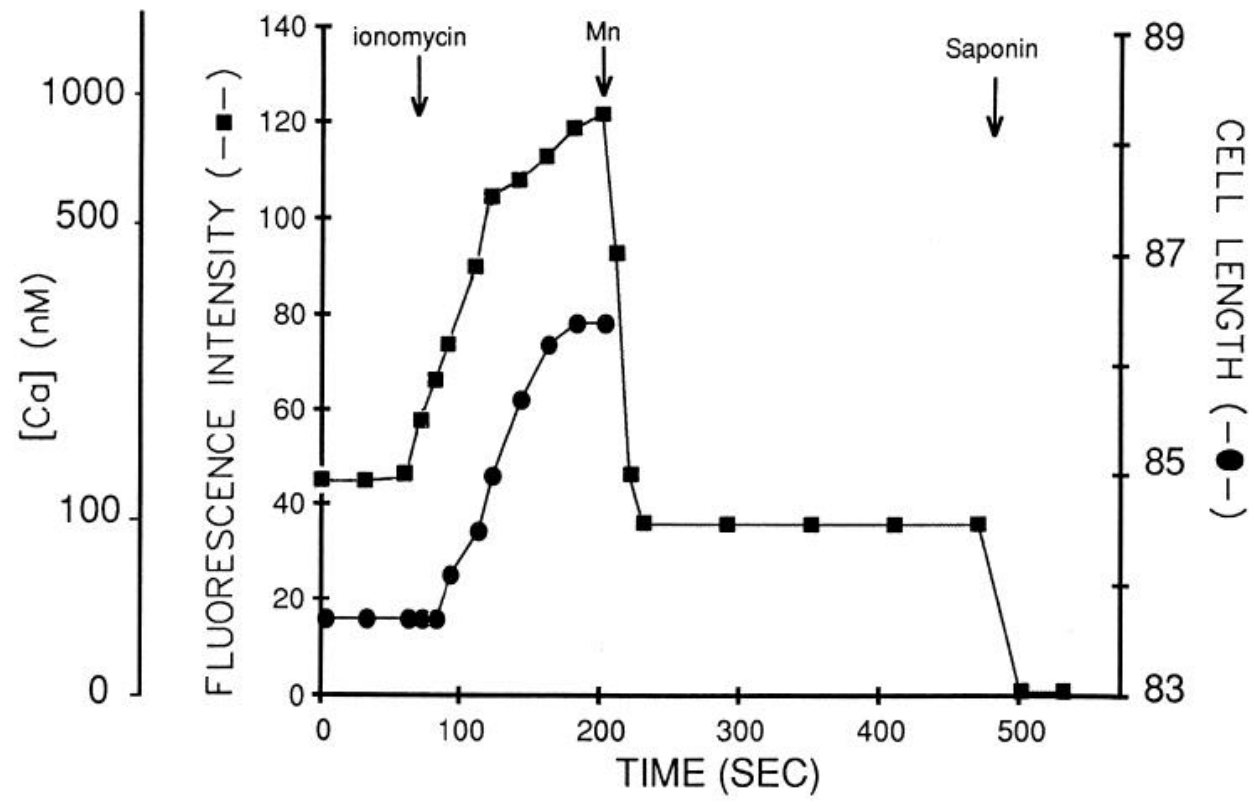

Figure 2. Response to ionomycin of outer hair cells loaded with fluo-3. Upper panel, Video microscopic images of the fluorescence of the same cell in HBSS before $(A), 60 \mathrm{sec}$ after ionomycin $(B)$, 2 min after $2 \mathrm{~mm} \mathrm{MnCl}_{2}(C)$, and 60 $\mathrm{sec}$ after $100 \mu \mathrm{g}$ saponin $/ \mathrm{ml}(D)$. Lower panel: Monitoring of cell length and changes of fluo-3 fluorescence of the same cell. The calibration scales shown beneath the cell images and as the y-axis of the chart were obtained as described in Materials and Methods. Cell length is given in $\mu \mathrm{m}$. nucleus before and after ionomycin treatment most likely indicates a nonhomogeneous distribution of the dye within the cell.

The fact that we do not measure an apparently complete equilibrium between external and internal calcium after ionophore treatment has its rationale in the complexity of the ionophore/membrane and the limitations of the dye/calcium interactions. The magnitude of the ionophore effect on calcium permeability may vary with the type of membrane, and increasing intracellular calcium is counteracted by calcium pumps in the plasma membrane. Second, the $\mathrm{Ca}^{2+}$-binding curve of the dye saturates above 5-10 $\mu \mathrm{M}$ calcium (Fig. 1), not permitting measurements of higher concentrations.

\section{Circumferential contractions of isolated outer hair cells}

Both basal and apical outer hair cells permeabilized for calcium by the ionophores elongated by $1-2 \mu \mathrm{m}$ (Table 1, Figs. 2, 3). The elongation was accompanied by a reduction in cell diameter and a decrease in cell volume of $269 \pm 220 \mu \mathrm{m}^{3}$ (5.0 $\pm 4.1 \%$; $n=14)$. The magnitude of the decrease in cell diameter varied along the length of the cell and was most pronounced in the middle. As measured in 3 representative areas, the reductions 

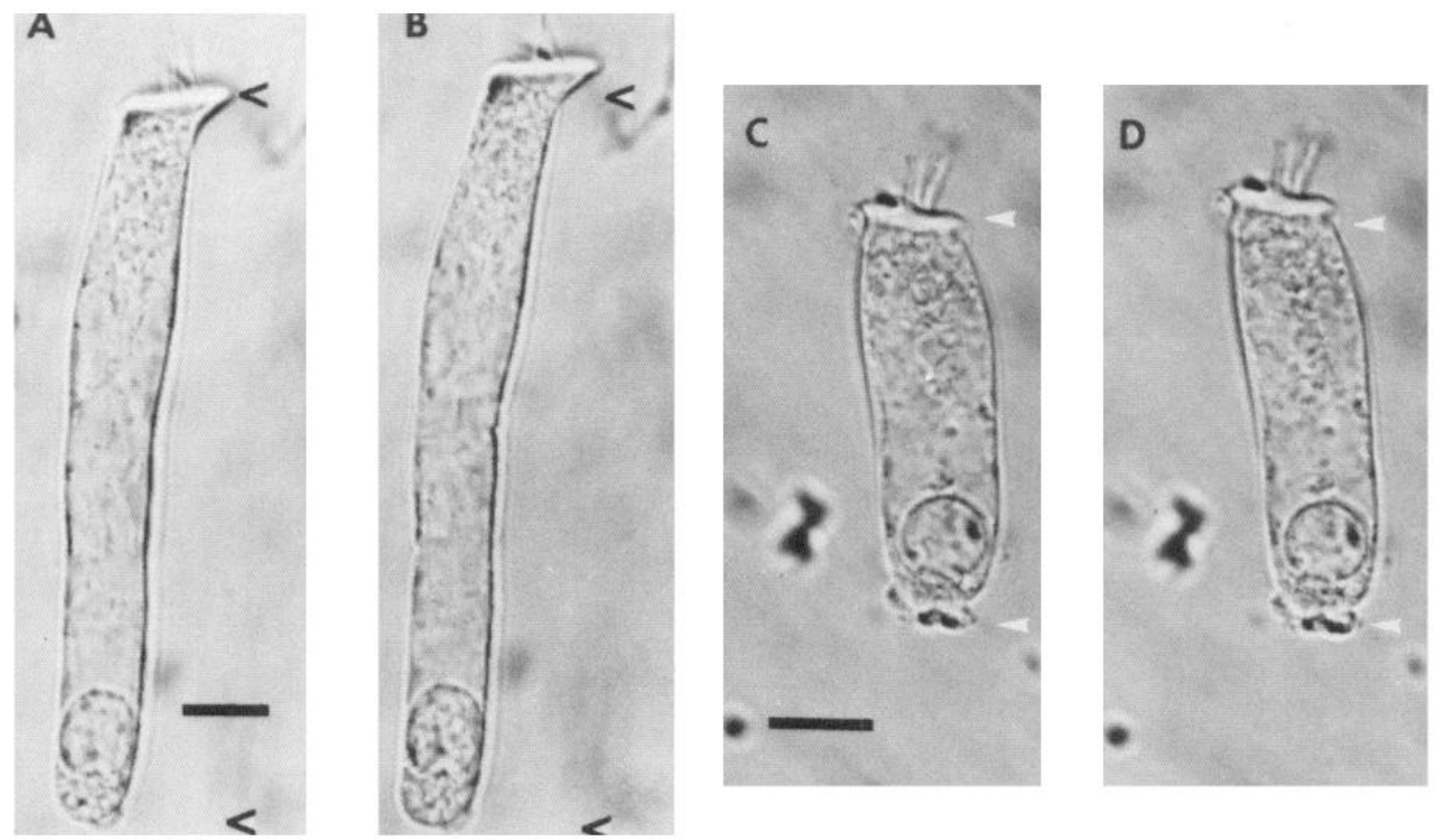

Figure 3. Cortical contraction in outer hair cells induced by the calcium ionophore ionomycin $(10 \mu \mathrm{M})$ in the presence of $1.25 \mathrm{mM}$ extracellular calcium. $A, B$, Same apical outer hair cell before $(A)$ and after $60 \mathrm{sec}$ of ionomycin-treatment $(B)$. $C, D$, Same basal outer hair cell before $(C)$ and after $60 \mathrm{sec}$ of ionomycin-treatment $(D)$. Calibration bars, $10 \mu \mathrm{m}$.

in diameter were: $3.1 \% \pm 4.8 \%$ in the apex near the cuticular plate ( $p=0.049$ as compared to controls by paired $t$ test), $4.4 \%$ $\pm 4.2 \%$ in the middle of the cell $(p<0.01)$, and there was no significant change $(1.1 \% \pm 5.8 \%)$ in the base around the nuclear region.

In the absence of intracellular fluo-3, the elongation of the cells and the reduction in cell diameter in response to calcium entry were observed to the same extent, indicating that the shape changes were not artifacts due to the intracellular presence of the calcium dye. In other control experiments, the application of $0.1 \%$ DMSO alone, corresponding to the final concentration added with the ionophores, did not lead to a significant change in cell shape or fluorescence (Table 1).

The cell response induced by ionomycin and calcium was reversed after the cells were rinsed with calcium-free HBSS (supplemented with 2 mм EGTA). Five of 6 cells observed returned after $120 \mathrm{sec}$ of exposure to a calcium-free medium to $99.3 \% \pm 1.7 \%$ of their original length.

\section{Optical imaging of the cell membrane by the fluorescent dye di-4-ANEPPS}

Preincubation of cells with the fluorescent dye di-4-ANEPPS allowed a good visualization of the plasma membrane contour (Fig. 4, representative of 6 observed cells). Before treatment with the calcium ionophore, the cell membrane along the lateral wall had a regular, smooth appearance (Fig. 4a). Upon addition of $10 \mu \mathrm{M}$ ionomycin in the presence of $1.25 \mathrm{~mm}$ calcium, the cell elongation was accompanied by changes in the cell contour (Fig. 4, b, c): the lateral cell membranes showed a wavy outline and delineated a smaller cell diameter. The subsequent substitution of the calcium-HBSS by a calcium-free medium supplemented with 2 mM EGTA led to a reverse reaction of the cell membrane. While the cell membrane became regular, the cells increased in diameter and shortened (Fig. $4 d$ ), confirming the observations made under bright-field optics.

\section{Requirement for extracellular calcium}

When outer hair cells were rinsed and incubated in calciumfree HBSS (supplemented with 2 mм EGTA) for $5 \mathrm{~min}$, the addition of $10 \mu \mathrm{M}$ ionomycin still produced an increase in both intracellular calcium and cell length (Fig. $5 A$ ). However, in all cells observed $(n=7)$ the elevation of calcium and the accompanying elongation were transient. The cells generally recovered their original cell length and fluorescence after $60 \mathrm{sec}$ (Table 1), further corroborating the correlation between calcium and cell length as well as the reversibility of the effect.

When outer hair cells $(n=7)$ were rinsed and bathed in calcium-free HBSS (supplemented with 2 mм EGTA) for a prolonged period of $30 \mathrm{~min}$ to $1 \mathrm{hr}$, the addition of $10 \mu \mathrm{M}$ ionomycin no longer led to changes in cell length and intracellular calcium levels (Fig. $5 B$ ). The subsequent addition of calcium-HBSS, however, produced the expected increase in cell length and fluorescence, indicating that the earlier absence of cell response was not due to cell deterioration or dye leakage.

\section{F-actin labeling with TRITC-phalloidin}

Since the main force-generating mechanism in both muscle and nonmuscle cells seems to be actomyosin, we localized F-actin in outer hair cells. The cuticular plate, the stereocilia, and a network underneath the cell membrane were strongly stained by TRITC-labeled phalloidin, a specific F-actin probe (Fig. 6). The F-actin network appeared to constitute a ring along the cell body extending from the cuticular plate to the synaptic ending (Fig. 6B). This fluorescent pattern was similarly observed wheth- 


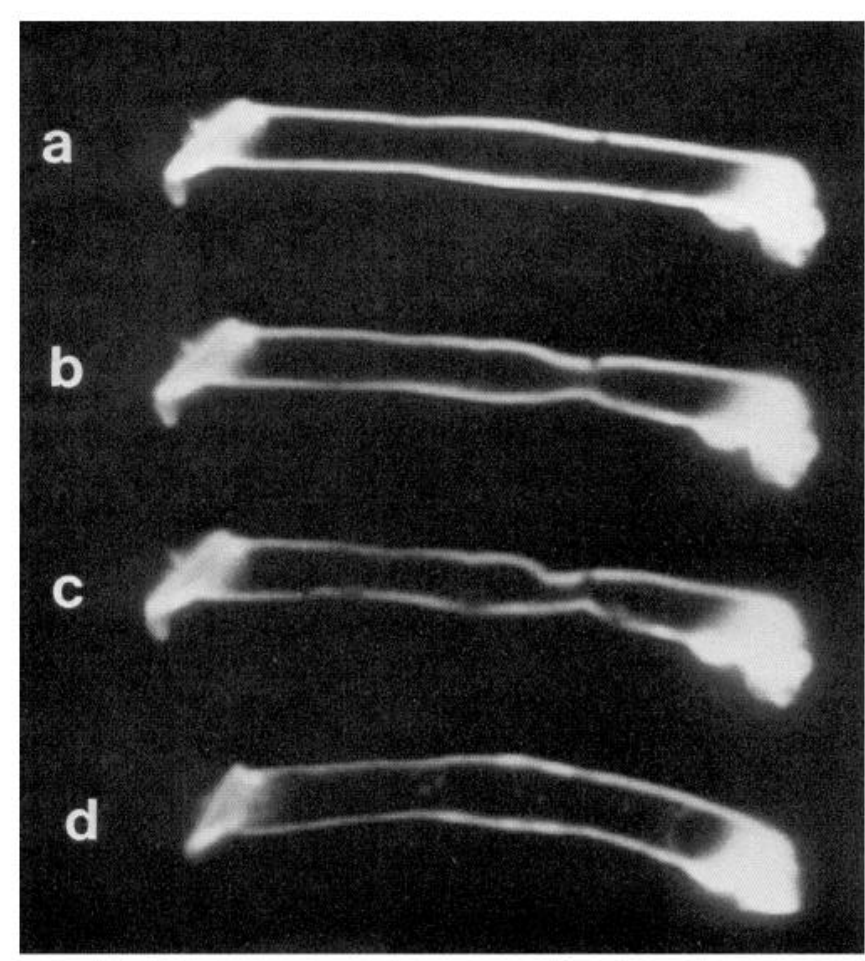

Figure 4. Optical imaging of the cell membrane with the potential dye di-4-ANEPPS during cortical contraction. Same outer hair cell in calcium-HBSS: $a$, Unstimulated state. $b, c$, After $15 \mathrm{sec}$ and $30 \mathrm{sec}$ with $10 \mu \mathrm{M}$ ionomycin. $d$, After $60 \mathrm{sec}$ in calcium-free HBSS (supplemented with 2 mM EGTA).

er outer hair cells were isolated from the base or the apex of the cochlea. An additional infracuticular F-actin network extending from the cuticular plate down to approximately $1 / 3$ of the cell length was observed only in outer hair cells from the apex and not from the base of the cochlea, in agreement with Thorne et al. (1987).

\section{Effect of TEA and calmodulin inhibitors}

Outer hair cells have been demonstrated to have a calciumactivated $\left[\mathrm{K}^{+}\right]$-current (Ashmore and Meech, 1986; Santos-Sacchi and Dilger, 1988). Therefore, a loss of cellular potassium during an increase in intracellular calcium might occur and produce an osmotic cell response. We tested for this possibility by applying TEA, which is known to block $\left[\mathrm{K}^{+}\right]$-outward current in outer hair cells (Santos-Sacchi and Dilger, 1988). The presence in the extracellular medium of $25 \mathrm{~mm}$ TEA did not inhibit the cellular response induced by $10 \mu \mathrm{M}$ ionomycin. Cell elongation in the presence of TEA reached a similar amplitude of $1.7 \pm 0.9 \%(n=5)$.

In order to determine whether calcium-receptive proteins such as calmodulin were involved in the calcium-induced cell contraction, we tested the effects of the calmodulin inhibitors trifluoperazine and pimozide. Both drugs inhibited the cell elongation induced by ionomycin. Of 9 cells observed in the presence of $30 \mu \mathrm{M}$ pimozide, none elongated or changed morphology after the application of $10 \mu \mathrm{M}$ ionomycin. Of an additional 8 cells observed in the presence of $30 \mu \mathrm{M}$ trifluoperazine, none elongated while intracellular calcium still increased (Fig. 7).
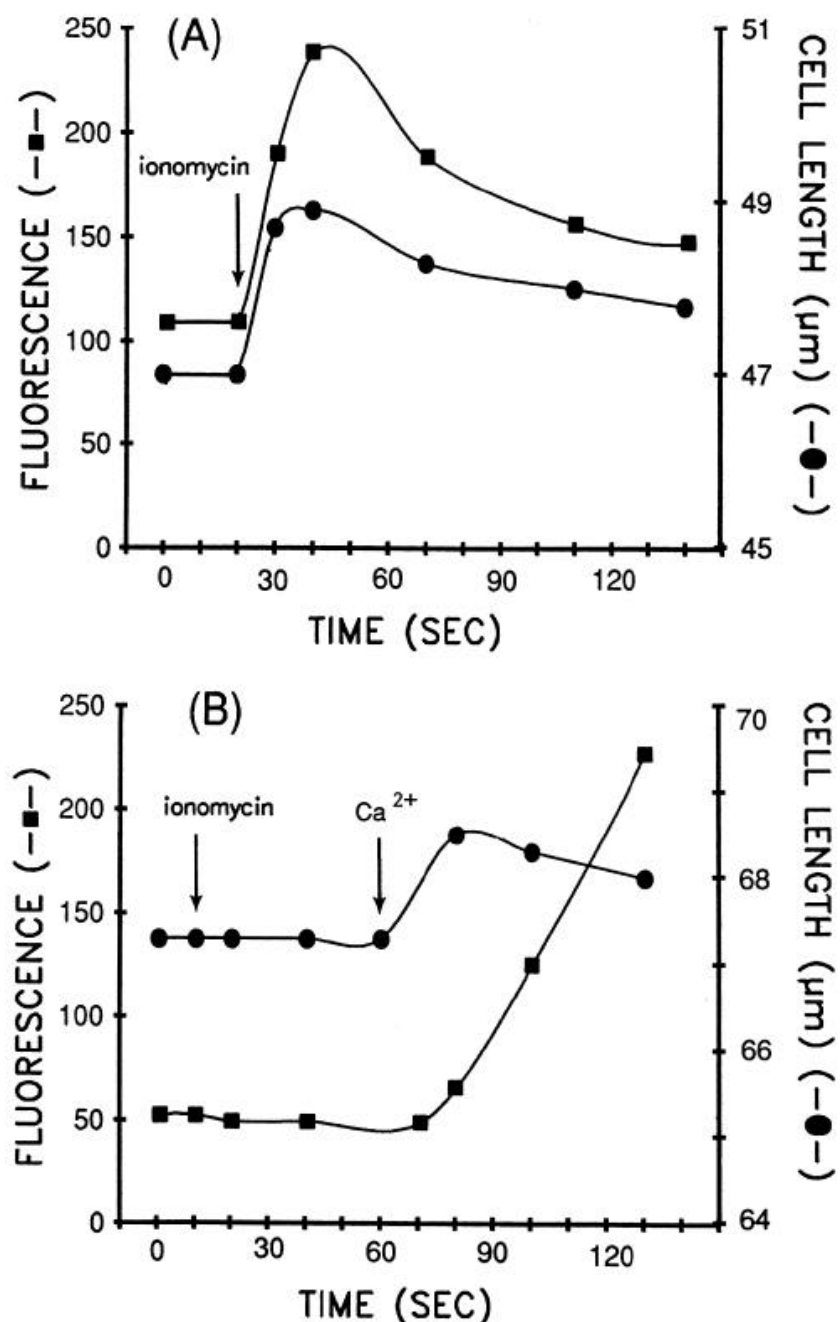

Figure 5. Effects of ionomycin on cell length and calcium-dependent fluorescence in the absence of extracellular calcium. Outer hair cells loaded with the fluorescent calcium indicator were washed and incubated in calcium-free HBSS supplemented with 2 mM EGTA for 5 min $(A)$ or $45 \mathrm{~min}(B)$. At the time indicated by the arrows, ionomycin (10 $\mu \mathrm{M})$ or $\mathrm{CaCl}_{2}(1.25 \mathrm{~mm})$ was added to the medium.

Effect of acetylcholine, carbachol, GABA, and phorbol ester on intracellular calcium and cell shape

The application to the extracellular medium of acetylcholine, carbachol, or GABA changed neither intracellular calcium concentration nor cell shape of basal or apical outer hair cells (for each condition: $n>20$ for morphological observations in bright field and $n>10$ for calcium-signal observations). Phorbol ester, an activator of protein kinase $\mathrm{C}$, also did not change intracellular calcium or cell shape $(n=10)$.

\section{Effect of calcium on cell tonicity}

The consequences of hypoosmotic shock on the shape and volume of outer hair cells were examined at different levels of intracellular calcium. As previously described (Dulon et al., 1987), both basal and apical outer hair cells reacted to hypotonicity of the extracellular medium by shortening and swelling (Fig. 8). The subsequent addition of $10 \mu \mathrm{M}$ ionomycin to the hypoosmotic medium led within $30 \mathrm{sec}$ to a reduction in cell 
Figure 6. Fluorescence images of TRITC-phalloidin staining in outer hair cells. Outer hair cells were permeabilized and incubated with TRITC-phalloidin as described in Materials and Methods. $A$, Longitudinal microscopic view of an outer hair cell. $B$, Video image of the fluorescent ring around the cell body which is visible in hair cells that were not lying flat on the cover slip. This cell presented a radial view of its basal part. $C P, N W$, and $\mathrm{R}$ indicate the position of the cuticular plate, the infracuticular network, and the ring associated with the plasma membrane, respectively.
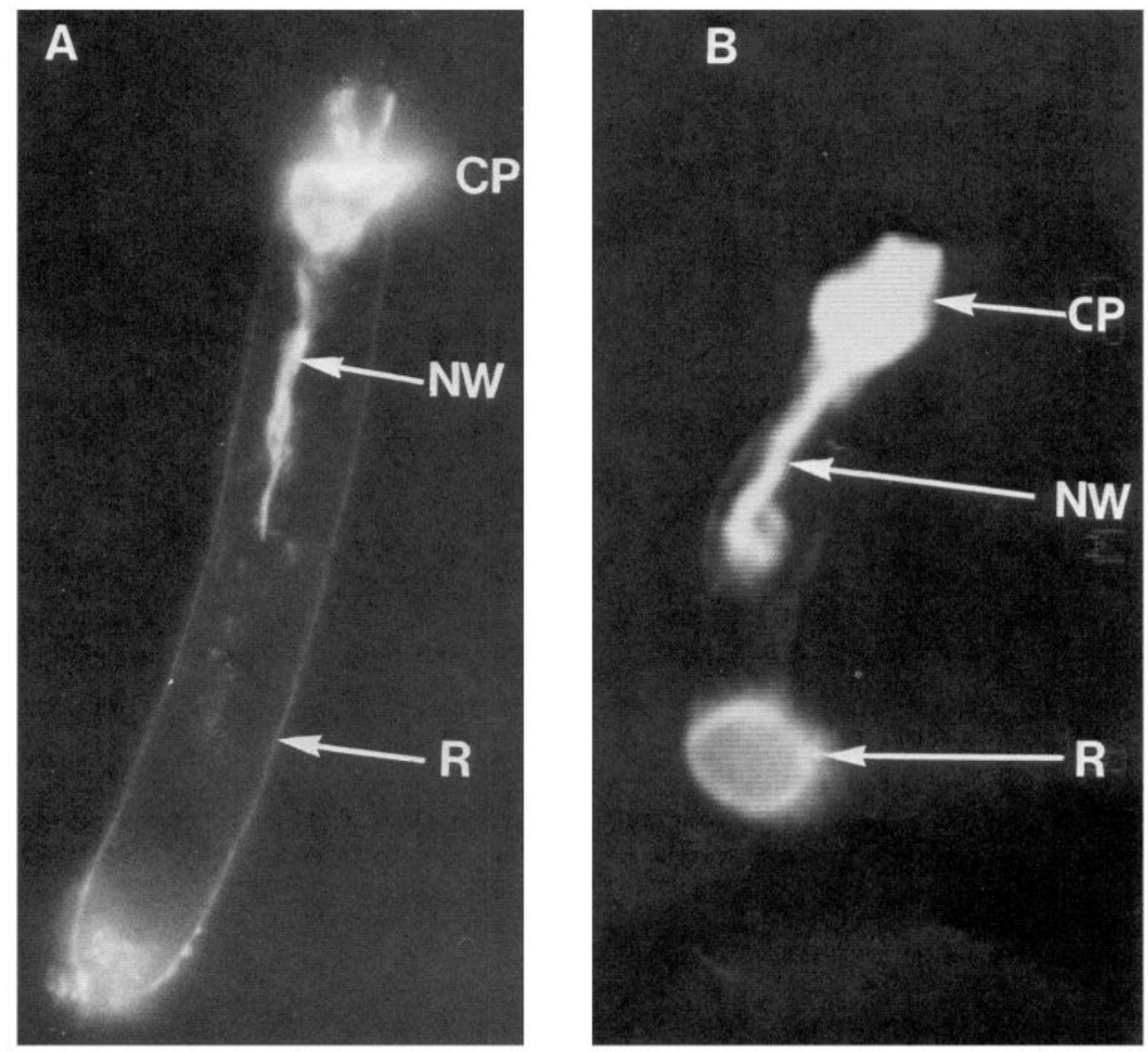

diameter and elongation, indicating cortical forces counteracting the osmotic effect (Fig. 8).

The relationship between cell deformation (changes in volume) and hypotonicity was then studied in detail. Control cells were maintained in the absence of ionophore in regular HBSS

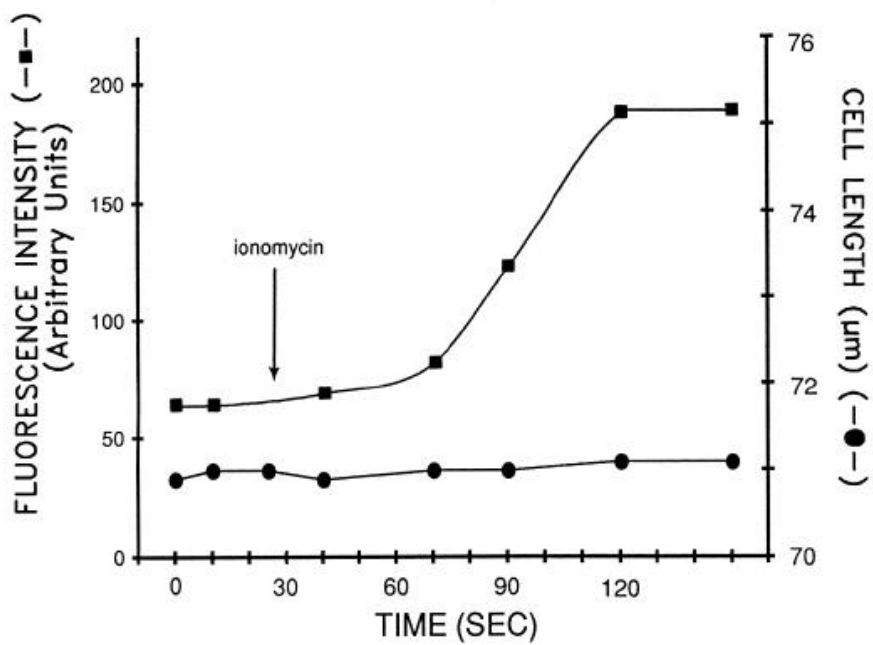

Figure 7. Effect of trifluoperazine on ionomycin-induced calcium increase and cell elongation. Hair cells were incubated for $30 \mathrm{~min}$ in HBSS containing $30 \mu \mathrm{M}$ of the calmodulin inhibitor before the addition of 10 $\mu \mathrm{M}$ of the calcium ionophore. $\left(1.25 \mathrm{~mm} \mathrm{CaCl}_{2}\right.$ ) or at low intracellular calcium obtained after 1-2 min treatment of cells with ionomycin $(10 \mu \mathrm{M})$ in calciumfree medium supplemented with $2 \mathrm{~mm}$ EGTA. Both types of controls showed similar increases in cell volume of 22,30 , and $50 \%$ after $60-120 \mathrm{sec}$ treatment with hypotonic media of 268 , 244 , and $217 \mathrm{mOsm}$, respectively. The magnitude of changes in cell volume presented an inverse linear relationship with the osmotic pressure of the extracellular medium (Fig. 9). In the presence of $1.25 \mathrm{~mm}$ external calcium, ionomycin-treated cells (60 sec at $10 \mu \mathrm{M})$ responded to a decrease of the osmolality of the extracellular medium again with an inverse linear relationship (Fig. 9). However, the slope of the response curve was reduced by $50 \%$, indicating a stronger resistance to deformation under hypotonic conditions.

\section{Discussion}

The ionophoric antibiotics A23187 and ionomycin are able to increase rapidly the concentration of intracellular free calcium in isolated outer hair cells. The elevation of intracellular calcium in turn generates circumferential or cortical forces leading to a reduction of cell diameter and an elongation of the cell. The fact that a transient elevation of cytoplasmic free calcium was still observed in the absence of external calcium indicates that, besides permeabilizing the plasma membrane for calcium, the ionophores may also induce calcium release from intracellular stores, as demonstrated in other cell types (Artalejo and GarciaSancho, 1988; Smith et al., 1989). In either case, the cell elongation was dependent on and directly correlated with the rise 

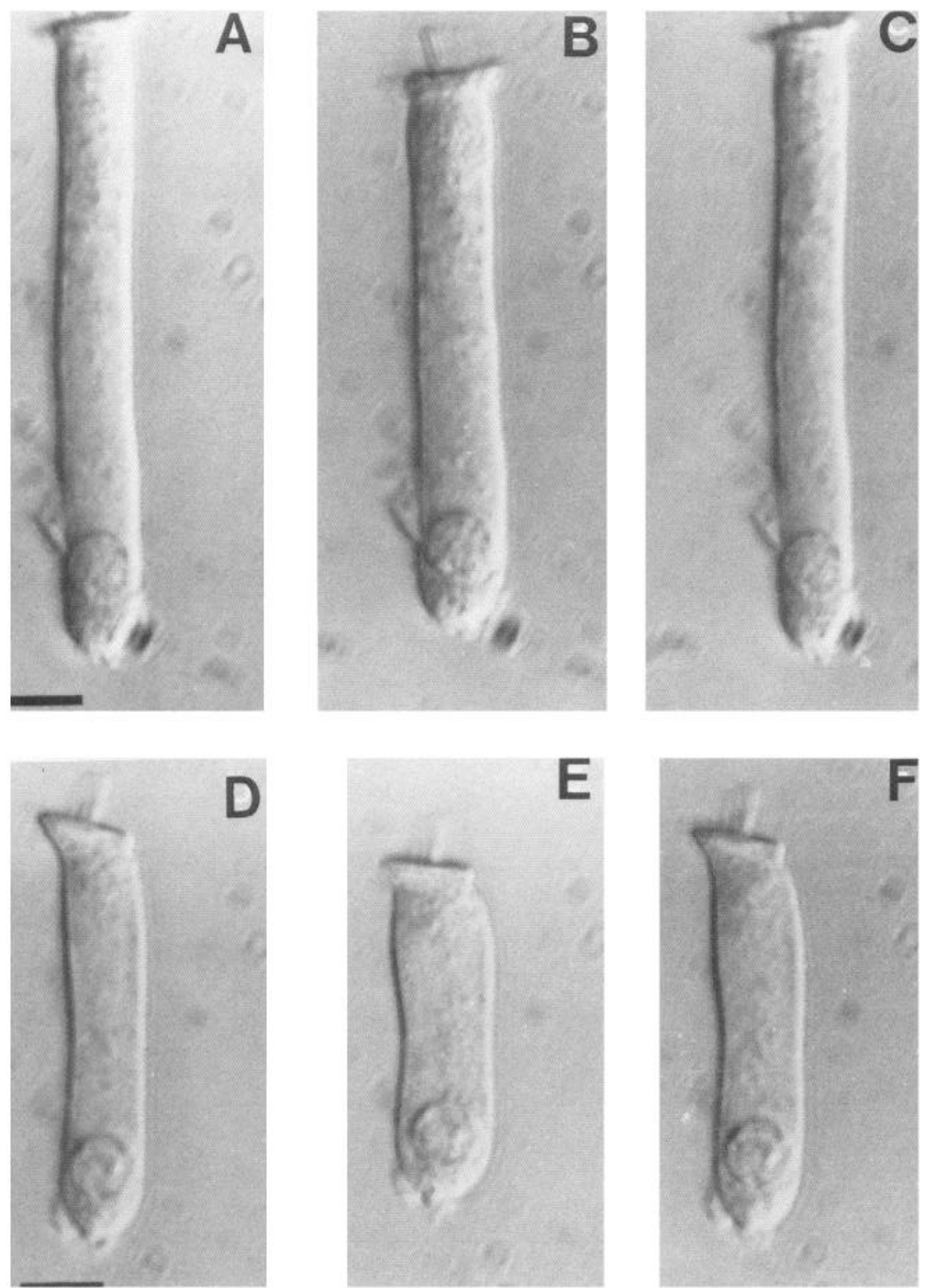

Figure 8. Changes in cell shape induced by hypotonicity of the extracellular medium in outer hair cells from the apex $(A, B, C)$ and the base of the cochlea $(D, E, F) . A$ and $D$, Outer hair cells in normal HBSS (300 mOsm). $B$ and $C$, Same cells after a 60 -sec exposure to HBSS of osmolality of 250 mOsm. $E$ and $F$, Same cells $60 \mathrm{sec}$ after the addition of $10 \mu \mathrm{M}$ ionomycin in HBSS (250 mOsm). in intracellular calcium and reversible upon reduction of calcium levels.

Several possible mechanisms might generate these cortical motive forces. First, the cell deformation could be due to an osmotic mechanism as we have demonstrated for $\left[\mathrm{K}^{+}\right]$-induced shape changes in these cells (Dulon et al., 1988). Since $\left[\mathrm{Ca}^{2+}\right]-$ dependent $\left[\mathrm{K}^{+}\right]$channels and $\left[\mathrm{Cl}^{-}\right]$channels are known to exist in outer hair cells (Ashmore and Meech, 1986; Gitter et al., 1986; Santos-Sacchi and Dilger, 1988), the increase in cytoplasmic calcium might produce a loss of $\mathrm{KCl}$ and generate a concomitant loss of water inducing shrinkage in cell volume. This phenomenon is indeed generated by calcium ionophores in a number of cell types (Grinstein et al., 1982; Hoffmann, 1985). However, such a mechanism appears to be unlikely for the cell shape changes observed in our study. The $\left[\mathrm{K}^{+}\right]$-channel blocker TEA, known to block outward current in outer hair cells (Santos-Sacchi and Dilger, 1988), did not inhibit the cell elongation induced by the calcium ionophore.
A second possible mechanism underlying the cell shape changes could be a change of intracellular $\mathrm{pH}$. In fact, the ionophore ionomycin is a $\left[\mathrm{Ca}^{2+}\right] /\left[\mathrm{H}^{+}\right]$exchanger (Gomperts et al., 1981) and has been shown to produce moderate intracellular alkalinization in several cell types (Di Virgilio and Gomperts, 1983; Grinstein and Cohen, 1987). However, while ionomycin is an obligatory $\left[\mathrm{Ca}^{2+}\right] /\left[\mathrm{H}^{+}\right]$exchanger, the other ionophore, A23187, can also transfer $\left[\mathrm{Mg}^{2+}\right]$ and has been shown not to modify intracellular pH in neutrophils (Di Virgilio and Gomperts, 1983). Furthermore, since the cell responses were still elicited in the absence of extracellular calcium, the cortical motive forces appeared not simply based on variations of intracellular $\mathrm{pH}$.

A third and most likely mechanism is suggested by the block of the cell response by the calmodulin inhibitors. The proposed mechanism then involves a contractile apparatus requiring the interaction of intracellular calcium-receptive proteins such as calmodulin with contractile proteins. The behavior of the cell membrane (as imaged with the potentiometric dye di-4- 


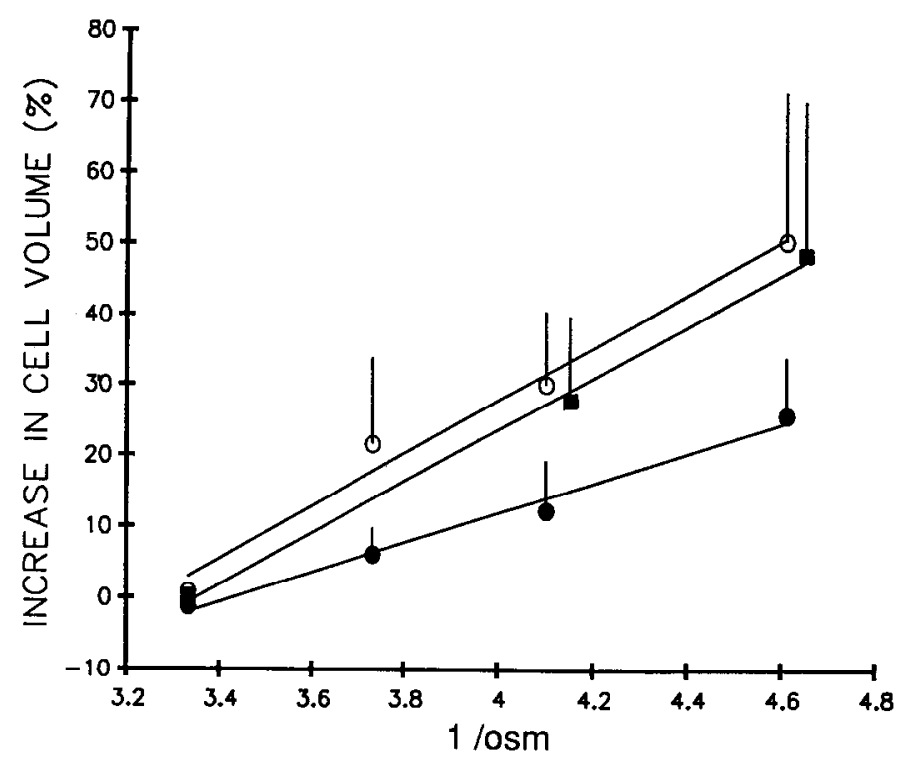

Figure 9. Relationship between cell volume of outer hair cells and osmotic pressure of the extracellular medium: (1) Control; cells were exposed to normal $\mathrm{Ca}^{2+}$ levels in HBSS ($\square$ ). By linear regression, the relation between volume and osmotic pressure was $Y=-112.1+$ 34.7X, with a coefficient of correlation $r=0.996$. (2) Control; cells were exposed to a 30 -sec pretreatment with ionomycin $(10 \mu \mathrm{M})$ in the absence of extracellular calcium (O): $Y=-114.8+34.6 X ; r=0.986$. (3) Cells were exposed to a 30 -sec pretreatment with ionomycin $(10 \mu \mathrm{M})$ in the presence of $1.25 \mathrm{~mm}$ external $\mathrm{CaCl}_{2}(\Theta): Y=-62.5+18.5 X ; r=0.999$ Each point is the mean of 5-6 cells and the vertical bars indicate the standard deviation. Each value in condition 3 was significantly different $(p<0.01)$ from conditions 1 and 2 .

ANEPPS) during calcium entry indeed suggests that the contractile event is closely associated with the plasma membrane. Moreover, we had previously provided suggestive evidence that the plasma membrane and the submembrane cortex are responsible for the maintenance of the elongated cylindrical shape of the cells (Dulon et al., 1989). Outer hair cells indeed possess a submembranous cortex composed of membranous cisternae and a lattice of cross-linked filaments (Saito, 1983; Raphael and Wroblewski, 1986; Holley and Ashmore, 1988). Although the precise nature of this latter filamentous network associated with the cisternae beneath the cell membrane is unknown, the staining by TRITC-phalloidin indicates the presence of F-actin, in agreement with previous reports (Flock et al., 1986; Slepecky et al., 1988). Cortical (circumferential) contractions involving actomyosin have been described in several nonmuscle cell types such as leukocytes and epidermal cells (Stossel et al., 1981; Strohmeier and Bereiter-Hahn, 1987). In these cells, the contractile forces acting in the cell cortex modify intracellular pressure which results in net movement. Therefore, the cortical apparatus underneath the membrane of the outer hair cell may produce a calcium-dependent elongation by contracting the diameter of the cell and by pressing the hyaloplasm toward the base and the cuticular area of the cell.

The contractile responses of the outer hair cells observed during calcium entry via the ionophores differ from previous studies demonstrating calcium-dependent axial contractions in outer hair cells (Flock et al., 1986; Zenner, 1986). In these studies, shortening of the cell body was demonstrated in cells permeabilized by detergents and exposed to calcium/ATP. It seems difficult to reconcile the different behavior of the cells. However, it may well be that the contractile apparatus associated with the cell membrane and involved in cortical contractions is destroyed by detergent treatment of the plasma membrane. This may have also been the case when cells were penetrated by microelectrodes to allow for passive diffusion of calcium/ATP (Dulon et al., 1988). More important, both detergent treatment and penetration by the microelectrode should have modified the intracellular hydrostatic pressure negating the generation of force-dependent cell elongation. In any case, a major shortcoming of previous demonstrations of calcium-induced hair cell contractility is their lack of reversibility, which makes a physiological interpretation difficult.

The physiological significance and the cellular trigger of calcium-induced cortical contractions in outer hair cells remain to be defined. The phorbol ester TPA did not elicit a calcium increase or contractile response, suggesting that phosphorylation reactions via protein kinase $C$ cannot be implied in the cell response. Moreover, it appears that neither acetylcholine (or carbachol) nor GABA is able to increase intracellular calcium or to elicit contractile responses in isolated outer hair cells. On the other hand, we have recently shown that intracellular calcium can be directly elevated in isolated outer hair cells upon $\left[\mathrm{K}^{+}\right]$-depolarization, presumably through the activation of voltage-dependent calcium channels. This calcium entry counteracted the cell shortening induced by depolarization (Dulon et al., 1989), in good agreement with results reported here. We might then speculate that the efferent system is involved in the regulation of channel activity rather than in the direct production of contractile responses.

The hypothesis of cortical or circumferential contractions as a mechanism operating in outer hair cells is reinforced by the calcium-mediated modulation of the cell volume response to hypotonicity. By lowering the osmolality of the extracellular medium, water influx tends to increase cell volume and impose cccentric forces against the membranous lateral wall of the outer hair cells (Dulon et al., 1987). As a consequence of this water influx, outer hair cells swell and shorten. In general, volume changes of living cells are inversely proportional to the osmotic pressure of the extracellular medium obeying van't Hoff's law. This relationship has been described for living cells by the equation: $P(V-b)=k$, where $P$ is the osmotic pressure, $V$ is the total cell volume, $b$ is the nonsolvent volume of the cell, and $k$ is a constant characteristic of the cell (Dick, 1959). The linear relationship between cell volume of the outer hair cells and osmotic pressure indicates that they follow this law. The observation that this relationship was altered in cells with high intracellular calcium (response slope reduced by $50 \%$ compared to control cells) demonstrates an enhanced capability of the outer hair cells to resist deformation under hypo-osmotic conditions. This argues strongly for the existence of calcium-dependent radial forces which increase the stiffness of the cell plasma membrane and the turgor of the cell.

In conclusion, the present study demonstrates reversible calcium-dependent cell elongations in outer hair cells. While the precise molecular basis remains to be established, the evidence suggests that the underlying contractile events occur within the cell cortex and involve calmodulin. These circumferential contractions may play an important role in the physiology of the outer hair cells, such as the control of cell shape and deformability, which may in turn influence the cochlear micromechanics. 


\section{References}

Artalejo, A. R., and J. Garcia-Sancho (1988) Mobilization of intracellular calcium by extracellular ATP and by calcium ionophores in the Ehrlich ascites-tumour cells. Biochim. Biophys. Acta 941: 48-54.

Ashmore, J. F. (1987) A fast motile response in guinea-pig outer hair cells: The cellular basis of cochlear amplifier. J. Physiol. (Lond.) 388: 323-347.

Ashmore, J. F., and R. W. Meech (1986) Ionic basic of membrane potential in outer hair cells of guinea pig cochlea. Nature $322: 368$ 371.

Brownell, W. E., C. R. Bader, D. Bertrand, and Y. de Ribeaupierre (1985) Evoked mechanical responses of isolated outer hair cells. Science 227: 194-196.

Dallos, P. (1985) Response characteristics of mammalian cochlear hair cells. J. Neurosci. 5: 1591-1608.

Dick, D. A. T. (1959) Osmotic properties of living cells. Int. Rev. Cytol. 8: $387-448$.

Di Virgilio, F., and B. D. Gomperts (1983) Cytosol $\mathrm{Mg}^{2+}$ modulates $\mathrm{Ca}^{2+}$ ionophore induced secretion from rabbit neutrophils. FEBS Lett. 163: 315-318.

Dulon, D., J.-M. Aran, and J. Schacht (1987) Osmotically induced motility of outer hair cells: Implications for Menière's disease. Arch. Otorhinolaryngol. 244: 104-107.

Dulon, D., G. Zajic, and J. Schacht (1988) [K+]-depolarization induces motility in outer hair cells by an osmotic mechanism. Hearing Res. 32: 123-130.

Dulon, D., G. Zajic, and J. Schacht (1989) Photo-induced irreversible shortening and swelling of isolated cochlear outer hair cells. Int. J. Radiat. Biol. 55: 1007-1014.

Dulon, D., G. Zajic, J.-M. Aran, and J. Schacht (1989) Aminoglycoside antibiotics impair [ $\left.\mathrm{K}^{+}\right]$-depolarization-induced calcium entry but not motility in outer hair cells. J. Neurosci. Res. 24: 338-346.

Eybalin, M., and R. Pujol (1987) Choline acetyltransferase (ChAT) immunoelectron microscopy distinguishes at least 3 types of efferent synapses in the organ of Corti. Exp. Brain Res. 65: 261-270.

Eybalin, M., C. Parnaud, M. Geffard, and R. Pujol (1988) Immunoelectron microscopy identifies several types of GABA-containing efferent synapses in the guinea pig organ of Corti. Neuroscience 24: 29-38.

Fay, F. S., H. H. Shlern, W. C. Granger, and S. R. Taylor (1979) Aequorin luminescence during activation of single isolated smooth muscle cells. Nature 280: 506-508.

Flock, A., B. Flock, and M. Ulfendahl (1986) Mechanisms of movement in OHCs and a possible structural basis. Arch. Otorhinolaryngol. 243: 83-90.

Gitter, A. H., H. P. Zenner, and E. Fromter (1986) Membrane potential and ion channels in isolated outer hair cells of guinea cochlea. O.R.L. 48: 68-75.

Gomperts, B. D., J. P. Bennett, and D. Allan (1981) A synthetic ionophore for $\mathrm{Ca}^{2+}$ : Studies with model and biological systems. Eur. J. Biochem. 117: 559-562.

Grinstein, S., and S. Cohen (1987) Cytoplasmic $\left[\mathrm{Ca}^{2+}\right]$ and intracellular pH in lymphocytes. J. Gen. Physiol. 89: 185-213.

Grinstein, S., A. Dupre, and A. Rothstein (1982) Volume regulation by human lymphocytes, role of calcium. J. Gen. Physiol. 79: 849868.

Gross, D., L. Loew, and W. W. Webb (1986) Optical imaging of cell membrane potential changes induced by applied electric fields. Biophys. J. 50: 339-348.

Hoffmann, E. L. (1985) Role of separate $\mathrm{K}^{+}$and $\mathrm{Cl}$ - channels and of $\mathrm{Na}^{+} / \mathrm{Cl}$ - cotransport in volume regulation in Ehrlich cells. Fed. Proc. 44: $2513-2519$.
Holley, M. C., and J. F. Ashmore (1988) A cytoskeletal spring in cochlear outer hair cells. Nature 335: 635-637.

Kachar, B., W. E. Brownell, R. Altschuler, and J. Fex (1986) Electrokinetic shape changes of cohlear outer hair cells. Nature 322: 365368.

Kao, J. P. Y., A. T. Harootunian, and R. Y. Tsien (1989) Photochemically generated cytosolic calcium pulses and their detection by fluo-3. J. Biol. Chem. 264: 8179-8184.

Konishi, M., A. Olson, S. Hollingworth, and S. M. Baylor (1988) Myoplasmic binding of fura- 2 investigated by steady-state fluorescence and absorbance measurements. Biophys. J. 54: 1089-1104.

Liu, C., and T. E. Hermann (1978) Characterization of ionomycin as a calcium ionophore. J. Biol. Chem. 253: 5892-5894.

Minta, A., Y. Kao, and R. Y. Tsien (1989) Fluorescent indicators for cytosolic calcium based on rhodamine and fluorescein chromophores. J. Biol. Chem. 264: 8171-8178.

Neely, S. T., and D. O. Kim (1986) A model for active elements in cochlear biomechanics. J. Acoust. Soc. Am. 79: 1472-1480.

Raphael, Y., and R. Wroblewski (1986) Linkage of sub-membranecisterns with the cytoskeleton and the plasma membrane in cochlear outer hair cells. J. Submicrosc. Cytol. 18: 731-737.

Reed, P. W., and H. A. Lardy (1972) A23187: A divalent cation ionophore. J. Biol. Chem. 247: 6970-6977.

Saito, K. (1983) Fine structure of the sensory epithelium of guineapig organ of Corti: Subsurface cisternae and lamellar bodies in the outer hair cells. Cell Tissue Res. 220: 787-795.

Santos-Sacchi, J., and J. P. Dilger (1988) Whole cell currents and mechanical responses of isolated outer hair cells. Hearing Res. 35: 143-150.

Slepecky, N., M. Ulfendahl, and A. Flock (1988) Effects of caffeine and tetracaine on outer hair cell shortening suggest intracellular calcium involvement. Hearing Res. 32: 11-22.

Smith, J. B., T. Zheng, and R.-M. Lyu (1989) Ionomycin releases calcium from the sarcoplasmic reticulum and activates $\mathrm{Na}^{+} / \mathrm{Ca}^{+}$exchange in vascular smooth muscle cells. Cell Calcium 10:125-134.

Stossel, T. P., J. H. Hartwig, H. L. Yin, and O. Stendahl (1981) The motor of amoeboid leucocytes. Biochem. Soc. Symp. 45: 51-63.

Strohmeier, R., and J. Bereiter-Hahn (1987) Hydrostatic pressure in epidermal cells is dependent on Ca-mediated contractions. J. Cell Sci. 88: 631-640.

Thorne, P. R., L. Carlisle, G. Zajic, J. Schacht, and R. A. Altschuler (1987) Differences in the distribution of F-actin in outer hair cells along the organ of Corti. Hearing Res. 30: 253-266.

Tsien, R. Y., T. Pozzan, and T. J. Rink (1982) Calcium homeostasis in intact lymphocytes: Cytoplasmic free calcium monitored with a new, intracellularly trapped fluorescent indicator. J. Cell Biol. 94: 325-334.

Warr, W. B., J. J. Guinan, Jr., and J. S. White (1986) Organization of the efferent fibers: The lateral and medial olivocochlear systems. In Neurobiology of Hearing: The Cochlea, R. A. Altschuler, D. W. Hoffman, and R. P. Bobbin, eds., pp. 333-348, Raven, New York.

Williams, D. A., K. E. Fogarty, R. Y. Tsien, and F. S. Fay (1985) Calcium gradients in single smooth muscle cells revealed by the digital imaging microscope using fura-2. Nature 318: 558-561.

Zajic, G., and J. Schacht (1987) Comparison of isolated outer hair cells from five mammalian species. Hearing Res. 26: 249-256.

Zenner, H. P. (1986) Motile responses in outer hair cells. Hearing Res. 22: 83-90.

Zenner, H. P., U. Zimmermann, and A. H. Gitter (1987) Fast motility of isolated mammalian auditory sensory cells. Biochem. Biophys. Res. Commun. 149: 304-308. 